\title{
Experimental Evidence of Large Changes in Terrestrial Chlorine Cycling Following Altered Tree Species Composition
}

\author{
Malin Montelius, ${ }^{\star \dagger} \dagger$ Yves Thiry, ${ }^{\ddagger}$ Laura Marang, ${ }^{\S}$ Jacques Ranger, $"$ Jean-Thomas Cornelis, ${ }^{\perp}$ \\ Teresia Svensson, ${ }^{\dagger}$ and David Bastviken ${ }^{\dagger}$ \\ ${ }^{\dagger}$ Department of Thematic Studies-Environmental Change, Linköping University, SE-581 83, Linköping, Sweden \\ ${ }^{\ddagger}$ Andra, Research and Development Division, Parc de la Croix Blanche, 1/7 rue Jean Monnet, 92298 Châtenay-Malabry Cedex, \\ France \\ ${ }^{\S}$ EDF, Laboratoire National d'Hydraulique et Environnement, 78401 Chatou, France \\ "Biogéochimie des écosystèmes forestiers, INRA Centre de Nancy, 54280 Champenoux, France \\ ${ }^{\perp}$ Soil Science Lab, Earth and Life Institute - Environmental Sciences, Université Catholique de Louvain, Croix du Sud 2/10, 1348 \\ Louvain-la-Neuve, Belgium
}

\section{Supporting Information}

ABSTRACT: Organochlorine molecules $\left(\mathrm{Cl}_{\text {org }}\right)$ are surprisingly abundant in soils and frequently exceed chloride $\left(\mathrm{Cl}^{-}\right)$levels. Despite the widespread abundance of $\mathrm{Cl}_{\text {org }}$ and the common ability of microorganisms to produce $\mathrm{Cl}_{\text {org }}$, we lack fundamental knowledge about how overall chlorine cycling is regulated in forested ecosystems. Here we present data from a long-term reforestation experiment where native forest was cleared and replaced with five different tree species. Our results show that the abundance and residence times of $\mathrm{Cl}^{-}$and $\mathrm{Cl}_{\text {org }}$ after 30 years were highly dependent on which tree species were planted on the nearby plots. Average $\mathrm{Cl}^{-}$and $\mathrm{Cl}_{\text {org }}$ content in soil humus were higher, at experimental plots with coniferous trees than in those with deciduous trees. Plots with Norway spruce had the highest net accumulation of $\mathrm{Cl}^{-}$and $\mathrm{Cl}_{\text {org }}$ over the experiment period, and showed a 10 and 4 times higher $\mathrm{Cl}^{-}$and $\mathrm{Cl}_{\text {org }}$ storage $(\mathrm{kg}$ $\mathrm{ha}^{-1}$ ) in the biomass, respectively, and 7 and 9 times higher storage of $\mathrm{Cl}^{-}$and $\mathrm{Cl}_{\text {org }}$ in the soil humus layer, compared to plots with oak. The results can explain why local soil chlorine levels are frequently independent of atmospheric deposition, and provide

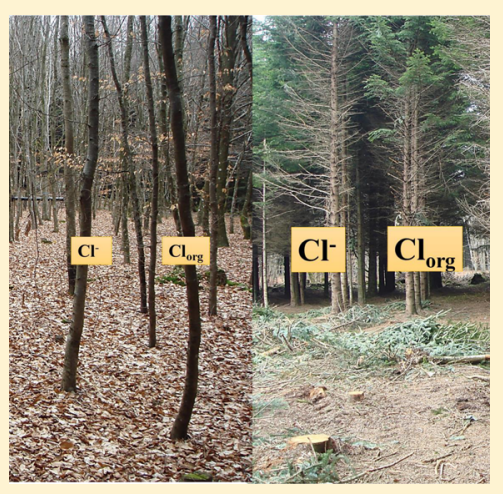
opportunities for improved modeling of chlorine distribution and cycling in terrestrial ecosystems.

\section{INTRODUCTION}

Tree species and their associated microbial communities play a central role in nutrient cycling in forest ecosystems. ${ }^{1,2}$ While chlorine $(\mathrm{Cl})$ is essential for healthy growth of higher plants, ${ }^{3}$ studies of interactions between trees and $\mathrm{Cl}$ are still rare. Instead, $\mathrm{Cl}$ biogeochemistry in terrestrial ecosystems has been of interest for several reasons other than plant interactions. Historically, it was believed that chloride $\left(\mathrm{Cl}^{-}\right)$was inert in soil and that transformation to organic chlorine $\left(\mathrm{Cl}_{\text {org }}\right)$ did not occur naturally. $\mathrm{Cl}^{-}$was then frequently used as a nonreactive tracer of soil and groundwater. ${ }^{4}$ In contrast, studies during recent decades show that $\mathrm{Cl}_{\text {org }}$ typically accounts for more than $60 \%$ of the total soil $\mathrm{Cl}$ pool in boreal and temperate forest soils, which led to suggestions of substantial natural chlorination. ${ }^{5,6}$ The natural and primarily biotic formation of this $\mathrm{Cl}_{\text {org }}$ pool has been confirmed experimentally, ${ }^{7-11}$ but the detailed content of the $\mathrm{Cl}_{\text {org }}$ pool and the reasons for its high abundance remain puzzling, and there is a lack of comprehensive $\mathrm{Cl}$ budgets for different ecosystems. ${ }^{12}$ The natural formation of $\mathrm{Cl}_{\text {org }}$ from $\mathrm{Cl}^{-}$has important consequences as it may influence the soil pool of $\mathrm{Cl}^{-}$available to organisms and vegetation and thereby the $\mathrm{Cl}$ cycling. The high chlorination rates and the large amounts of $\mathrm{Cl}_{\text {org }}$ found, ${ }^{13}$ and a large number of organisms being able to mediate chlorination (e.g., refs 14-16), indicates that the chlorine cycling is ubiquitous and may also have fundamental but yet unknown ecological implications. ${ }^{17,18}$ In addition, the radioisotope ${ }^{36} \mathrm{Cl}$ has recently caused concerns due to its presence in radioactive waste and its long half-life (301000 years). The fact that $\mathrm{Cl}$ are physiologically important for humans and other organisms, for example, in cellular ion balances, ${ }^{19}$ and the potentially rapid uptake of ${ }^{36} \mathrm{Cl}$ by plants and in the end humans, makes it desirable to account for in ${ }^{36} \mathrm{Cl}$ radioactive risk assessment models. Longer residence time of ${ }^{36} \mathrm{Cl}$ in soil means increased radiation exposure times to humans, plants and soil-systems in case of contamination. ${ }^{20}$ In spite of these implications we still lack fundamental knowledge about the spatial and temporal variability and the regulation of the processes involved in $\mathrm{Cl}$ cycling. Even very fundamental spatial patterns of $\mathrm{Cl}$

Received: January 9, 2015

Revised: March 26, 2015

Accepted: March 26, 2015

Published: March 26, 2015 

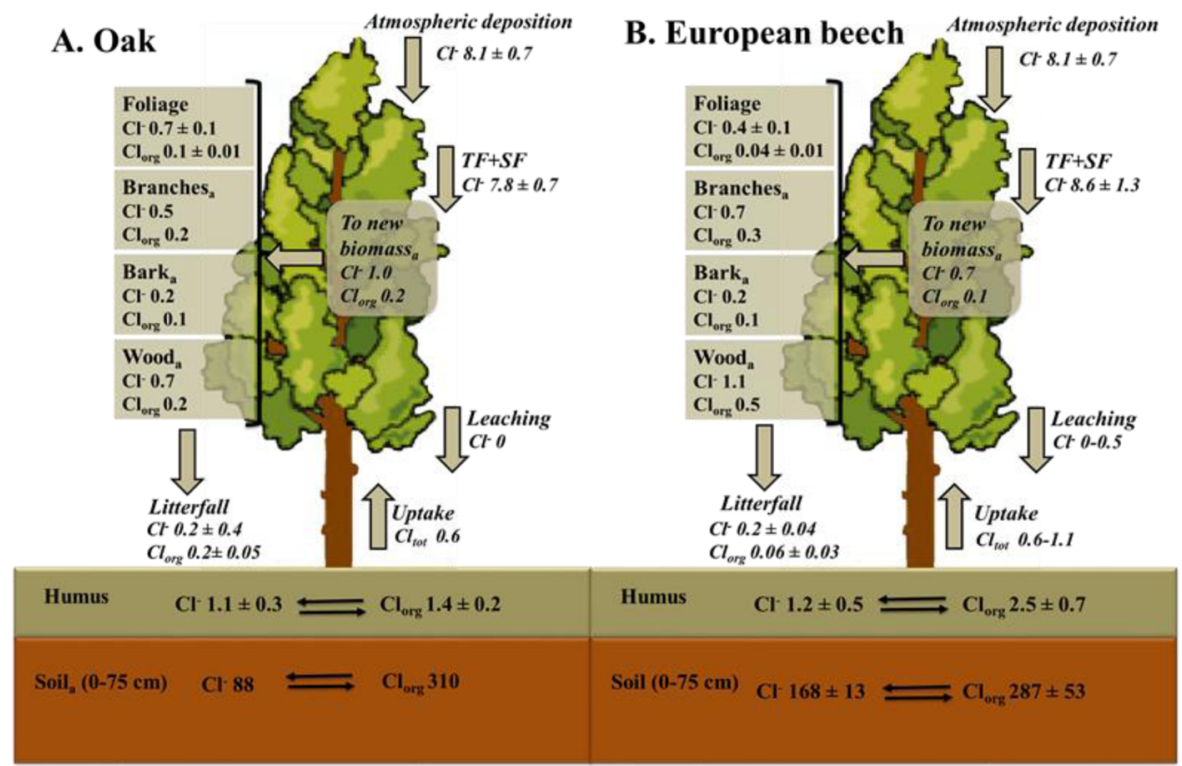

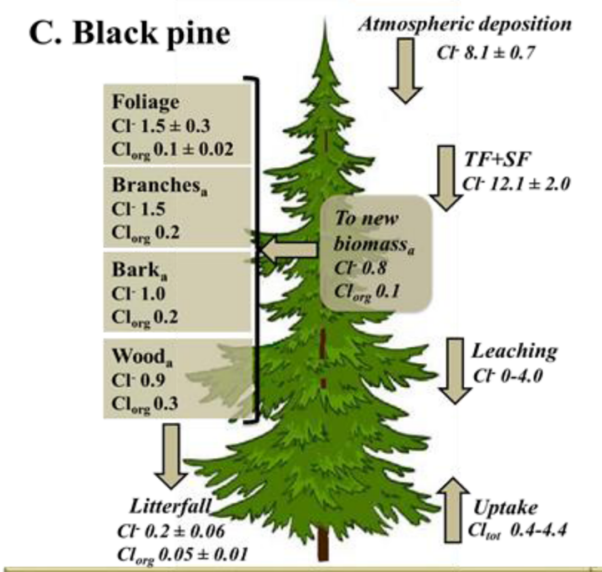

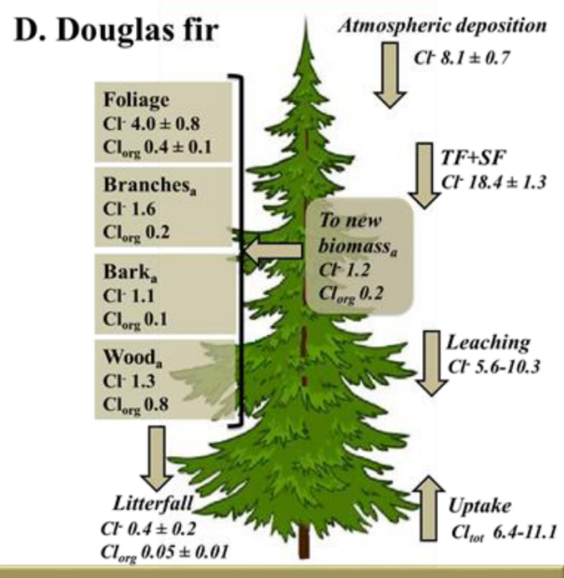

E. Norway spruce
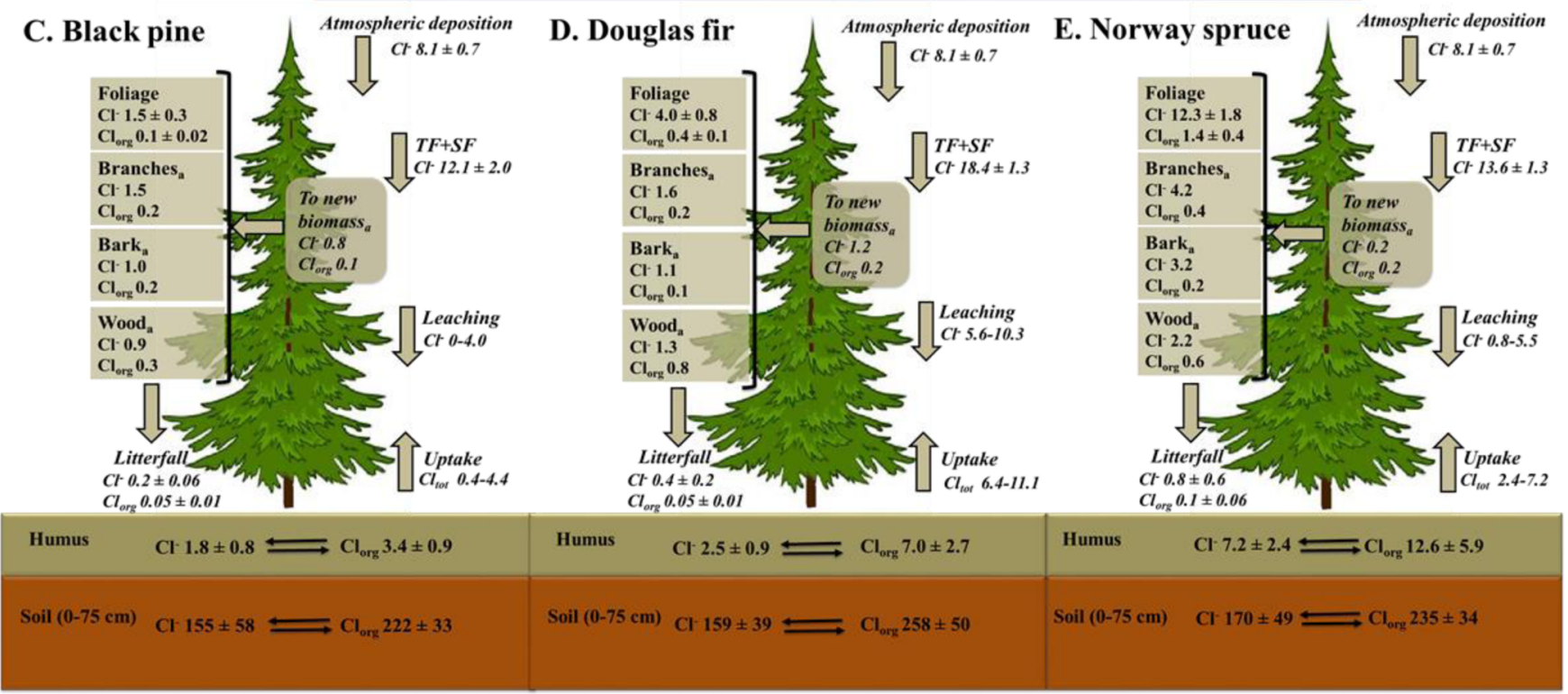

Figure 1. Budget $\left(\mathrm{kg} \mathrm{ha}^{-1}\right)$ and fluxes $\left(\mathrm{kg} \mathrm{ha}^{-1} \mathrm{y}^{-1}\right.$; fluxes shown in italics) of chloride $\left(\mathrm{Cl}^{-}\right)$and organic chlorine $\left(\mathrm{Cl}_{\text {org }}\right)$ in tree stands with oak $(\mathrm{A})$, European beech (B), black pine (C), Douglas fir (D), and Norway spruce (E), at the experimental forest site at Breuil-Chenue (in the east of France) established in 1976 and sampled during 2002-2005. TF+SF denote the sum of throughfall and stemflow. Values are presented as means \pm standard deviation ( $n=5$ for atmospheric deposition, throughfall, foliage, and litterfall including leaves and branches; $n=8$ for humus; $n=3$ for mineral soil down to $75 \mathrm{~cm}$ below the humus). The remaining components are presented with average values for composite samples from three replicates (denoted by the subscript "a"). The maximal analytical variability was $2 \%$. Leaching and uptake are calculated as explained in the Supporting Information. Thick gray arrows denote fluxes and the black arrows denote possible transformations between $\mathrm{Cl}^{-}$and $\mathrm{Cl}_{\text {org }}$.

distribution remain unexplained, and local levels of $\mathrm{Cl}$ in soils can deviate substantially from the expected large scale input from wet and dry atmospheric deposition of $\mathrm{Cl}$.

Previous attempts to study what controls $\mathrm{Cl}$ abundance and transformation rates have been based on small-scale laboratory experiments detached from full ecosystems, or correlations between $\mathrm{Cl}$ levels and monitored environmental variables where cause-effect relationships are unclear. ${ }^{6,7,21-24}$ At large scales, the distance to the sea and the climatic factors including precipitation has been suggested to determine $\mathrm{Cl}$ levels. ${ }^{12}$ At local scales these patterns do not remain and recently the cycling between the soil pools of $\mathrm{Cl}^{-}, \mathrm{Cl}_{\text {org }}$ and organic matter was suggested to be responsible for the high local variability in overall soil $\mathrm{Cl}$ levels. ${ }^{22}$ Importantly, the conclusion of previous studies exploring spatial patterns of $\mathrm{Cl}$ in terrestrial environ- ments could only hypothesize, but not confirm, cause-effect relationships.

Here we turn our attention to the potential influence of trees (including both direct effects from the trees themselves, and indirect effects from tree-related environmental factors such as soil processes and soil microbial communities) on terrestrial $\mathrm{Cl}$ cycling. Trees have a major influence on most elements serving as nutrients in forests. The tree canopies influence the amount and chemical composition of litterfall and throughfall. Trees can also influence the nutrient availability through rhizosphere processes ${ }^{25}$ such as $\mathrm{N}_{2}$ fixation, mineral weathering by root exudates, root uptake, and other soil processes. ${ }^{2}$ There are differences in bacterial and fungal communities in litter, forest floor, and soil that can be attributed to various dominating tree species. $^{26}$ 
Table 1. Distribution of Total Chlorine ( $\mathrm{Cl} ; \mathrm{mg} \mathrm{Cl} \mathrm{kg}^{-1}$ Dry Weight) And Percentage of Organic Chlorine $\left(\% \mathrm{Cl}_{\text {org }}\right)$ in $\mathrm{Material}$ from Trees and Soil at the Experimental Plots Planted with Different Tree Species ${ }^{a}$

\begin{tabular}{|c|c|c|c|c|c|c|c|c|c|c|}
\hline \multirow[b]{2}{*}{ component } & \multicolumn{2}{|c|}{ oak } & \multicolumn{2}{|c|}{ European beech } & \multicolumn{2}{|c|}{ black pine } & \multicolumn{2}{|c|}{ Douglas fir } & \multicolumn{2}{|c|}{ Norway spruce } \\
\hline & $\mathrm{Cl}$ & $\% \mathrm{Cl}_{\text {org }}$ & $\mathrm{Cl}$ & $\% \mathrm{Cl}_{\text {org }}$ & $\mathrm{Cl}$ & $\% \mathrm{Cl}_{\text {org }}$ & $\mathrm{Cl}$ & $\% \mathrm{Cl}_{\text {org }}$ & $\mathrm{Cl}$ & $\% \mathrm{Cl}_{\text {org }}$ \\
\hline foliage & 235 & 15 & 183 & 8 & 196 & 7 & 253 & 8 & 424 & 10 \\
\hline branches & 26 & 30 & 19 & 32 & 82 & 10 & 54 & 10 & 133 & 9 \\
\hline bark & 26 & 28 & 26 & 30 & 79 & 18 & 54 & 5 & 296 & 5 \\
\hline wood & 12 & 23 & 10 & 30 & 12 & 23 & 14 & 38 & 27 & 21 \\
\hline litterfall (leaves) & 93 & 41 & 90 & 17 & 69 & 20 & 127 & 9 & 269 & 13 \\
\hline litterfall (branches) & 53 & 65 & 45 & 54 & 100 & 73 & 61 & 34 & 117 & 43 \\
\hline humus & 126 & 57 & 138 & 67 & 149 & 66 & 201 & 74 & 317 & 64 \\
\hline soil $^{b} 0-7.5 \mathrm{~cm}$ & 85 & 82 & 131 & 61 & 87 & 63 & 113 & 63 & 127 & 59 \\
\hline soil $^{b} 7.5-15 \mathrm{~cm}$ & 77 & 84 & 99 & 68 & 75 & 46 & 77 & 53 & 81 & 54 \\
\hline soil $^{b} 15-30 \mathrm{~cm}$ & 48 & 71 & 55 & 55 & 60 & 58 & 47 & 65 & 53 & 59 \\
\hline soil $^{b} 30-45 \mathrm{~cm}$ & 34 & 78 & 35 & 73 & 33 & 66 & 31 & 60 & 31 & 70 \\
\hline soil $^{b} 45-60 \mathrm{~cm}$ & 25 & 84 & 27 & 67 & 29 & 66 & 27 & 71 & 29 & 57 \\
\hline soil $^{b} 60-75 \mathrm{~cm}$ & 25 & 71 & 29 & 58 & 32 & 60 & 29 & 57 & 23 & 50 \\
\hline
\end{tabular}

${ }^{a}$ See Materials and Methods and Figure 1 for information about sample replication and standard deviation. ${ }^{b}$ The mineral-bound $\mathrm{Cl}$ fraction in the soil samples $\left(4.7 \pm 0.2 \mathrm{mg} \mathrm{Cl} \mathrm{kg}{ }^{-1}\right.$ dry weight across all plots) was small compared to $\mathrm{Cl}^{-}$and $\mathrm{Cl}_{\text {org }}$ pools.

The research regarding uptake of $\mathrm{Cl}$ by plants have been focused on agriculture. A field study on agriculture crop uptake of ${ }^{36} \mathrm{Cl}$ during three vegetation seasons showed a retention of ${ }^{36} \mathrm{Cl}$ in the soil system based on observations that ${ }^{36} \mathrm{Cl}$ is taken up by vegetation through root uptake. ${ }^{27}$ No mineral sorption was observed. Kashparov et al. ${ }^{28}$ showed that ${ }^{36} \mathrm{Cl}$ taken up by the biota is released quickly from dry vegetation without decomposition. There were however no separation of $\mathrm{Cl}^{-}$and $\mathrm{Cl}_{\text {org }}$ in these studies making their relative contributions unknown. Forest and single trees species have been studied in connection to precipitation and throughfall. $\mathrm{Cl}^{-}$were generally measured more frequently than $\mathrm{Cl}_{\text {org }}$, but $\mathrm{Cl}_{\text {org }}$ concentrations in throughfall and soil has been measured in forest plots to study potential sources of $\mathrm{Cl}_{\text {org }}$ (e.g., refs 29,30).

The previous studies provided important information about chlorine distribution and speciation in forest ecosystems. They have revealed striking inconsistencies between local heterogeneity and the larger scale patterns of potential regulator variables (e.g., between local $\mathrm{Cl}_{\text {org }}$ levels and chlorine deposition), ${ }^{22}$ and generated multiple hypotheses to explain the inconsistencies. However, there has been a lack of experimental studies at the ecosystem level being able to address cause-effect relationships. In the present study we investigated if tree species influence overall terrestrial $\mathrm{Cl}$ cycling in an experimental forest ecosystem and studied the balance between $\mathrm{Cl}^{-}$and $\mathrm{Cl}_{\text {org }}$ in the soil and in different plant parts. The study thereby represents an ecosystem experiment, aiming to reveal potential cause-effect relationships linking $\mathrm{Cl}$ cycling with the establishment of different tree species.

\section{MATERIALS AND METHODS}

The experimental forest used in this study is located at BreuilChenue, Bourgogne, in eastern France (latitude $47^{\circ} 18^{\prime} 10^{\prime \prime} \mathrm{N}$; longitude $4^{\circ} 4^{\prime} 44^{\prime \prime} \mathrm{E}$ ). The original soil at this site is an acid brown soil, classified as an Alumnic Cambisol (IUSS Working Group WRB 2006), developed from granite that is very poor in major cations $(0.5 \%$ magnesium oxide, $0.6 \%$ calcium oxide and $4.4 \%$ potassium oxide). The native forest, consisted of a previously coppiced woodland with beech (Fagus sylvatica), oak (Quercus sessiliflora), birch (Betula verrucosa), and hazel nut trees (Corylus avelana) as the dominating tree species. In 1975, an area of the native forest was cleared, to form a number of 0.1 ha plots, which were replanted with single tree species in 1976. Five of these replanted forest stands were chosen for this study: Douglas fir (Pseudotsuga menziesii), Norway spruce (Picea abies), black pine (Pinus nigra), European beech (Fagus sylvatica), and oak (Quercus sessiliflora). Triplicate samples of litterfall and ligneous parts of standing biomass (stem, bark, and branches), ${ }^{31}$ as well as samples of bulk humus layer soil (eight replicates per stand) and mineral soil (triplicate soil profiles, $n=$ 6 per profile) collected in 2005, and yearly samples of living foliage (2002-2006; five replicates per stand), were analyzed as described below. The tree biomass and litterfall were estimated according to ref 31 . We also had access to data on the $\mathrm{Cl}^{-}$ content in atmospheric deposition, throughfall and stemflow for the same period. The atmospheric deposition was collected daily at a central location next to the forest stands in an open deposition collector system. Throughfall was collected every month by double gutters (three replicates per forest stand). ${ }^{31}$ Stemflow was collected by means of plastic collars attached to the trunks of 10 trees per stand selected to represent different growth classes. The $\mathrm{Cl}^{-}$concentrations were analyzed using ion chromatography (MIC-2, Metrohm). ${ }^{32}$

The amount of total $\mathrm{Cl}$ and the $\mathrm{Cl}_{\text {org }}$ content in soil and tree compartments were determined stepwise by analyses of total halogens (TX) and total organic halogens (TOX) by adding sieved and milled soil and tree samples to a small crucible followed by combustion at $1000{ }^{\circ} \mathrm{C}$ in an $\mathrm{O}_{2}$ atmosphere using an ECS3000 analyzer (Euroglas). ${ }^{33}$ Before the TOX analyses the samples were leached with acidic nitrate solution $(6 \times 3$ $\mathrm{mL}, 0.01 \mathrm{KNO}_{3}, 0.001 \mathrm{M} \mathrm{HNO}_{3}$ ), followed by acidified Milli-Q water $\left(6 \times 3 \mathrm{~mL},<\mathrm{pH} 2\right.$ by acidification with $\left.\mathrm{HNO}_{3}\right)$, to remove any remaining $\mathrm{Cl}^{-33}$. The same type of combustion as described above then returned $\mathrm{Cl}_{\text {org }}$ plus possible mineral bound $\mathrm{Cl}\left(\mathrm{Cl}_{\text {mineral }}\right)$ in the mineral soils samples. In the mineral soil samples we therefore also determined the possible $\mathrm{Cl}_{\text {mineral }}$ content by analyzing samples after precombustion of organic matter at $500{ }^{\circ} \mathrm{C}$ for $4 \mathrm{~h}$ and leaching to remove all nonmineral $\mathrm{Cl}^{-}$. The $\mathrm{Cl}_{\text {mineral }}$ was then subtracted to yield $\mathrm{Cl}_{\text {org }}$ in these samples. $\mathrm{Cl}^{-}$was calculated by subtracting values of $\mathrm{Cl}_{\text {org }}$ and $\mathrm{Cl}_{\text {mineral }}$ from the total $\mathrm{Cl}$.

Based on all available data of biomass stocks and fluxes, ${ }^{31}$ their $\mathrm{Cl}^{-}$and $\mathrm{Cl}_{\text {org }}$ concentrations, as well as of $\mathrm{Cl}^{-}$deposition, stemflow and throughfall, we estimated ecosystem $\mathrm{Cl}^{-}$and $\mathrm{Cl}_{\text {org }}$ 
Table 2. Overview of the Average Annual Fluxes Involved in Plant Cl Cycling for Different Tree Species Planted in the Same Type of Soil ${ }^{a}$

\begin{tabular}{|c|c|c|c|c|c|}
\hline & \multicolumn{5}{|c|}{ annual total $\mathrm{Cl}$ flux $\left(\mathrm{kg} \mathrm{ha}^{-1} \mathrm{y}^{-1}\right)$} \\
\hline & oak & European beech & Black pine & Douglas fir & Norway spruce \\
\hline \multicolumn{6}{|l|}{ Incorporation in Biomass } \\
\hline trunk wood & 0.06 & 0.14 & 0.02 & 0.17 & 0.18 \\
\hline trunk bark & 0.02 & 0.02 & 0.02 & 0.10 & 0.20 \\
\hline branches & 0.07 & 0.11 & 0.05 & 0.18 & 0.34 \\
\hline $\begin{array}{l}\text { total annual incorporation in biomass } \\
\text { return }\end{array}$ & 0.16 & 0.27 & 0.09 & 0.45 & 0.72 \\
\hline litterfall (foliage) & 0.30 & 0.24 & 0.25 & 0.38 & 0.87 \\
\hline litterfall (branches) & 0.09 & 0.04 & 0.01 & 0.03 & 0.05 \\
\hline total litterfall & 0.40 & 0.28 & 0.26 & 0.41 & 0.91 \\
\hline leaching $^{b}$ & 0 & $0-1.9$ & $0-5.5$ & $5.6-12.7$ & $1.1-5.8$ \\
\hline total return from litterfall and leaching ${ }^{c}$ & 0.4 & $0.3-2.2$ & $0.3-5.8$ & $8.3-13.1$ & $2.0-6.7$ \\
\hline uptake & 0.6 & $0.6-2.4$ & $0.4-5.9$ & $8.8-13.5$ & $2.8-7.5$ \\
\hline
\end{tabular}

${ }^{a_{1}}$ The detailed cycling of $\mathrm{Cl}^{-}$and $\mathrm{Cl}_{\text {org }}$, respectively, and the variability estimates are presented in Figure 1 . The calculations are described in the Supporting Information. ${ }^{b}$ The ranges given are based on a sensitivity analysis with two extreme scenarios for the contributions of dry deposition and leaching. One scenario assumes that the total deposition collector accurately captures all dry deposition, and the other scenario that the total dry deposition scavenged by canopies is 50\% of the total deposition (see Supporting Information for details). For oak, the throughfall plus stemflow was always slightly lower than the measured total deposition (Figure 1), which is why no range is given. ${ }^{c}$ The ranges reflect the sensitivity analysis described in a footnote a.

Table 3. Cl Pools, Litterfall, Accumulation in Humus Layer, And Mean Residence Time in Experimental Plots with Different Tree Species $^{a}$

\begin{tabular}{|c|c|c|c|c|c|}
\hline & oak & European beech & Black pine & Douglas fir & Norway spruce \\
\hline $\begin{array}{l}\text { atmospheric input } \\
\left(\mathrm{kg} \mathrm{ha}^{-1} \mathrm{y}^{-1}\right)\end{array}$ & $\begin{array}{l}8.1 \\
(7.4-8.8)\end{array}$ & $\begin{array}{l}8.1 \\
(7.4-8.8)\end{array}$ & $\begin{array}{l}8.1 \\
(7.4-8.8)\end{array}$ & $\begin{array}{l}8.1 \\
(7.4-8.8)\end{array}$ & $\begin{array}{l}8.1 \\
(7.4-8.8)\end{array}$ \\
\hline $\mathrm{Cl}^{-}$in tree species & 2.1 & 2.4 & 4.8 & 8.0 & 22 \\
\hline$\left(\mathrm{kg} \mathrm{ha}^{-1}\right)$ & $(1.2-2.9)$ & $(1.4-3.4)$ & $(3.2-6.5)$ & $(4.4-12)$ & $(9.9-34)$ \\
\hline $\begin{array}{l}\mathrm{Cl}_{\text {org }} \text { in tree species } \\
\left(\mathrm{kg} \mathrm{ha}^{-1}\right)\end{array}$ & $\begin{array}{l}0.6 \\
(0.58-0.64)\end{array}$ & $\begin{array}{l}0.9 \\
(0.88-0.94)\end{array}$ & $\begin{array}{l}0.8 \\
(0.6-1.0)\end{array}$ & $\begin{array}{l}1.5 \\
(1.4-1.5)\end{array}$ & $\begin{array}{l}2.5 \\
(2.2-2.9)\end{array}$ \\
\hline $\begin{array}{l}\mathrm{Cl}-\text { in humus } \\
\left(\mathrm{kg} \mathrm{ha}^{-1}\right)\end{array}$ & $\begin{array}{l}1.1 \\
(0.8-1.4)\end{array}$ & $\begin{array}{l}1.2 \\
(0.8-1.7)\end{array}$ & $\begin{array}{l}1.8 \\
(1.0-2.5)\end{array}$ & $\begin{array}{l}2.5 \\
(1.6-3.4)\end{array}$ & $\begin{array}{l}7.2 \\
(4.8-9.6)\end{array}$ \\
\hline $\begin{array}{l}\mathrm{Cl}_{\text {org }} \text { in humus } \\
\left(\mathrm{kg} \mathrm{ha}^{-1}\right)\end{array}$ & $\begin{array}{l}1.4 \\
(1.2-1.6)\end{array}$ & $\begin{array}{l}2.5 \\
(1.8-3.2)\end{array}$ & $\begin{array}{l}3.4 \\
(2.5-4.3)\end{array}$ & $\begin{array}{l}7.0 \\
(4.2-9.8)\end{array}$ & $\begin{array}{l}12.6 \\
(6.7-18.5)\end{array}$ \\
\hline $\begin{array}{l}\text { Net } \mathrm{Cl}_{\text {org }} \text { accumulation rate in } \\
\text { humus }\left(\mathrm{kg} \mathrm{Cl} \mathrm{ha}^{-1} \mathrm{y}^{-1}\right)\end{array}$ & $\begin{array}{l}0.13 \\
(0.09-0.17)\end{array}$ & $\begin{array}{l}0.08 \\
(0.05-0.11)\end{array}$ & $\begin{array}{l}0.05 \\
(0.03-0.07)\end{array}$ & $\begin{array}{l}0.13 \\
(0.08-0.18)\end{array}$ & $\begin{array}{l}0.28 \\
(0.15-0.41)\end{array}$ \\
\hline possible net contribution from & 0.11 & 0.02 & 0.008 & 0.01 & 0.05 \\
\hline $\mathrm{Cl}_{\text {org }}$ in litter $\left(\mathrm{kg} \mathrm{Cl} \mathrm{ha}^{-1} \mathrm{y}^{-1}\right)$ & $(0.09-0.13)$ & $(0.02-0.02)$ & $(0.006-0.01)$ & $(0.01-0.01)$ & $(0.04-0.06)$ \\
\hline $\begin{array}{l}\text { residence time of } \mathrm{Cl}^{-} \text {(tree) } \\
\text { (y) }\end{array}$ & $\begin{array}{l}6.2 \\
(3.6-8.7)\end{array}$ & $\begin{array}{l}1.0 \\
(0.58-5.9)\end{array}$ & $\begin{array}{l}0.8 \\
(0.5-17)\end{array}$ & 0.6 & 3.0 \\
\hline $\begin{array}{l}\text { residence time of } \mathrm{Cl}_{\text {org }} \text { (tree) } \\
\text { (y) }\end{array}$ & $\begin{array}{l}3.3 \\
(2.2-5.8)\end{array}$ & $\begin{array}{l}15 \\
(8.8-41)\end{array}$ & $\begin{array}{l}13 \\
(8.9-26)\end{array}$ & $\begin{array}{l}32 \\
(22-54)\end{array}$ & $\begin{array}{l}19 \\
(11-35)\end{array}$ \\
\hline residence time of $\mathrm{Cl}^{-}$(humus) & 0.1 & 0.2 & 0.2 & 0.3 & 0.9 \\
\hline (y) & $(0.1-0.2)$ & $(0.1-0.2)$ & $(0.1-0.3)$ & $(0.2-0.5)$ & $(0.5-1.3)$ \\
\hline $\begin{array}{l}\text { residence time of } \mathrm{Cl}_{\text {org }} \text { (humus) } \\
\text { (y) }\end{array}$ & $\begin{array}{l}11 \\
(8.2-15)\end{array}$ & $\begin{array}{l}30 \\
(22-45)\end{array}$ & $\begin{array}{l}65 \\
(46-111)\end{array}$ & $\begin{array}{l}52 \\
(44-63)\end{array}$ & $\begin{array}{l}45 \\
(34-68)\end{array}$ \\
\hline
\end{tabular}

${ }^{a} \mathrm{Cl}_{,} \mathrm{Cl}^{-}$and $\mathrm{Cl}_{\text {org }}$ denote total chlorine, chloride, and organic chlorine, respectively. The ranges presented correspond to \pm the maximum coefficient of variation for the data used in calculations, or the range given by the throughfall sensitivity analysis if larger (see Supporting Information for equations and explanations, as well as discussion of uncertainty ranges).

fluxes, and thereby the overall $\mathrm{Cl}$ cycling, for each plot as described in detail in the Supporting Information.

\section{RESULTS AND DISCUSSION}

Did the Change in Dominating Tree Species Affect the Chlorine Pools? The results showed that the experimental manipulation of dominating tree species clearly had influenced ecosystem levels of both $\mathrm{Cl}^{-}$and $\mathrm{Cl}_{\text {org }}$ almost 30 years after the reforestation treatment was initiated (Figure 1).
Total $\mathrm{Cl}$ concentrations per dry mass $\left(\mathrm{mg} \mathrm{kg}^{-1}\right)$ in both the tree tissue and the humus layer were higher in Norway spruce stands than in the other trees (Table 1; one-way ANOVA, $n=5$ for foliage and $n=8$ for humus, $p<0.0005$ ). Average $\mathrm{Cl}^{-}$and $\mathrm{Cl}_{\text {org }}$ content in soil humus were $1.5-6.5$ and 1.4-9 times higher, respectively, at experimental plots with coniferous trees than those with deciduous trees. When comparing the mass of total $\mathrm{Cl}$ per hectare $\left(\mathrm{kg} \mathrm{ha}^{-1}\right)$ accounting for tree specific differences in biomass, plots with Norway spruce were found to have the highest levels of $\mathrm{Cl}^{-}$and $\mathrm{Cl}_{\text {org }}$ in the humus of all 
plots, followed by Douglas fir plots, in turn having higher levels than the black pine, beech and oak plots (Figure 1; one-way ANOVA for humus, $n=8$; $p<0.0005$; Fisher's test in Minitab for group comparisons). This pattern was characteristic of most studied ecosystem components in the plots (Figure 1, Tables 1, 2, and 3). Compared to plots of oak, Norway spruce plots exhibited 10-fold and 4-fold higher $\mathrm{Cl}^{-}$and $\mathrm{Cl}_{\text {org }}$ storage (kg $\mathrm{ha}^{-1}$ ) in the biomass, respectively, and similarly, 7-fold and 9fold higher storage of $\mathrm{Cl}^{-}$and $\mathrm{Cl}_{\text {org }}$ in the humus layer (Table 3 ). However, levels were similar across plots in the mineral soil below the humus layer (Figure 1, Table 1). Thus, during a period of almost 30 years, which may be too short to affect deeper mineral soils, a change in dominating tree species had an influence on $\mathrm{Cl}$ cycling down to the humus layer, in spite of identical initial conditions at all plots when the trees were planted (Table 1 reveals a possible effect also in the uppermost mineral soil layer but no effect in the deeper mineral soil in support of the idea that it takes time for the effect to extend downward into the soil). Our results indicate that forest ecosystems with coniferous forests are likely to accumulate higher amounts of both $\mathrm{Cl}^{-}$and $\mathrm{Cl}_{\text {org }}$ compared to deciduous forest ecosystems, regardless of initial conditions. Such results could provide an explanation for the observed patterns in several previous studies. ${ }^{5,13}$ Thus, the dominating vegetation, including the absence or presence of trees and at the next level the tree species composition, are likely the main factor providing the frameworks for local terrestrial $\mathrm{Cl}$ cycling over time.

While this study can conclusively show that plots where different tree species established developed different $\mathrm{Cl}^{-}$and $\mathrm{Cl}_{\text {org }}$ levels in biomass, additional studies are needed to reveal the detailed mechanisms behind this. The trees themselves may contribute through internal production of $\mathrm{Cl}_{\text {org }}$ in biomass (Table 1) or by different $\mathrm{Cl}$ uptake (Table 2) affecting $\mathrm{Cl}$ residence times. However, the trees are perhaps more likely to have indirect effects on the $\mathrm{Cl}$ cycling by tree related soil microbial communities (including both mycorrhiza, wood degrading fungi, and bacteria) with different capacity of chlorinating organic matter, or by influencing the soil organic matter content shown to have effects on $\mathrm{Cl}_{\text {org }}$ levels. ${ }^{6,22}$ However, the organic carbon content only differed by a factor of 2 between oak and spruce plots and cannot explain all differences in $\mathrm{Cl}_{\text {org }}$ between the humus layers. The $\mathrm{Cl}_{\text {org }}$ normalized to carbon was $0.15,0.32,0.27,0.42$, and $0.59 \mu \mathrm{g}$ $\mathrm{Cl} \mathrm{mg} \mathrm{C}{ }^{1-}$ in the oak, beech, pine, Douglas fir and spruce plots, respectively; spruce plot values being significantly higher than values in the oak, beech and pine humus layers, one-way ANOVA, $n=8, p<0.05)$. This indicates that major differences in humus layer $\mathrm{Cl}_{\text {org }}$ levels between the plots remained after normalizing to organic carbon, for example, a 4-fold difference between oak and spruce plots remained that could not be explained by differences in organic carbon content. Thus, the humus layer $\mathrm{Cl}_{\text {org }}$ levels in the different plots were not only dependent on the organic matter content but also on the degree to which the organic matter is chlorinated.

Ecosystem $\mathrm{Cl}$ Fluxes. The ecosystem $\mathrm{Cl}$ fluxes were estimated to illustrate the influence of the experimental manipulation of tree species on overall $\mathrm{Cl}$ cycling (see Supporting Information and Tables 2 and 3). The estimated $\mathrm{Cl}$ fluxes follow the patterns seen in concentrations and standing stocks (described above). There was in general a more extensive $\mathrm{Cl}$ uptake by trees, higher accumulation of $\mathrm{Cl}_{\text {org }}$ in humus layers, and longer $\mathrm{Cl}$ residence times in coniferous tree stands than in the deciduous tree stands (Table 2, Table 3, Supporting Information). The flux estimates are based on data from less than 30 year old tree stands and any differences between the tree stands may increase as the experimental forest matures with increasing biomass and longer time for soil processes to develop in response to the changed tree species composition.

$\mathrm{Cl}_{\text {org }}$ Accumulation and Cycling. The estimated net humus $\mathrm{Cl}_{\text {org }}$ accumulation rates was $0.28 \mathrm{~kg} \mathrm{Cl} \mathrm{ha}^{-1} \mathrm{y}^{-1}$ in the Norway spruce stand and ranged from 0.05 to $0.13 \mathrm{~kg} \mathrm{Cl} \mathrm{ha}^{-1}$ $\mathrm{y}^{-1}$ in the other stands (Table 3). Previous mass balance estimates of top soil net chlorination in older spruce stands range from 0.35 to $0.5 \mathrm{~kg} \mathrm{Cl} \mathrm{ha}^{-1} \mathrm{y}^{-1} .30$ In a survey of various forests, Redon et al. ${ }^{6}$ estimated net humus $\mathrm{Cl}_{\text {org }}$ accumulation rates ranging from -0.92 to $0.48 \mathrm{~kg} \mathrm{Cl} \mathrm{ha}^{-1} \mathrm{y}^{-1}$, with negative rates in primarily oak and beech forests and positive rates mostly in Douglas fir, spruce, and pine forests. Thus, the previous mass balances, largely support the differences between species and the overall levels found here. It should be noted that local data on carbon and $\mathrm{Cl}$ fluxes was typically more limited in the previous studies than at the Breuil site, and therefore previous budgets had to rely on combining data from different locations. The negative values noted by ${ }^{6}$ may not be realistic over long time frames, as $\mathrm{Cl}_{\text {org }}$ were present in all soils, and the previous nonexperimental work could only speculate about reasons for the indicated patterns. However, the relative differences between dominating tree species found seem consistent with our results, which now conclusively show a cause-effect relationship between changes in tree species and the $\mathrm{Cl}$ cycling.

The net humus $\mathrm{Cl}_{\text {org }}$ accumulation should depend on either production of $\mathrm{Cl}_{\text {org }}$ in the humus layer or import of $\mathrm{Cl}_{\text {org }}$ from litterfall that are resistant enough to degradation to accumulate over time together with the recalcitrant organic matter in the soils. $\mathrm{Cl}_{\text {org }}$ constituted a relatively large fraction of total $\mathrm{Cl}$ in biomass in all the species studied (7-38\%; Table 1). Although the $\mathrm{Cl}_{\text {org }}$ contribution to the soil from litterfall varied between the tree stands, this import could potentially have supported a substantial part of the estimated net $\mathrm{Cl}_{\text {org }}$ accumulation in the humus layer in some tree stands (e.g., oak; Table 3). In a previous study it was shown that about half the $\mathrm{Cl}_{\text {org }}$ in leaves of white oak was aliphatic and seemed to be resistant to degradation. ${ }^{10}$ Hence, for unknown reasons, chlorination inside plants seems to be significant and could potentially contribute to the soil $\mathrm{Cl}_{\text {org }}$ pool through recalcitrant $\mathrm{Cl}_{\text {org }}$ in litterfall. However, for most of the forest stands the estimated net accumulation of $\mathrm{Cl}_{\text {org }}$ in humus by far exceeded the possible contribution from litterfall, showing that $\mathrm{Cl}_{\text {org }}$ from litter in many cases cannot support all the $\mathrm{Cl}_{\text {org }}$ accumulation in the humus layer. Thus, $\mathrm{Cl}_{\text {org }}$ formed by microorganisms upon organic matter decomposition, ${ }^{10,11}$ is likely the dominating source for the humus layer $\mathrm{Cl}_{\text {org }}$ pool in many environments.

In comparison with the estimated net humus $\mathrm{Cl}_{\text {org }}$ accumulation rates from ecosystem budgets (0.05-0.28 kg $\mathrm{ha}^{-1} \mathrm{y}^{-1}$ ), the gross chlorination rates determined in laboratory experiments with humus from a spruce forest were substantially higher and ranged from 1 to $9 \mathrm{~kg} \mathrm{Cl} \mathrm{ha}^{-1} \mathrm{y}^{-1} \cdot 22$ The difference in chlorination rates between the field and laboratory (i.e., between long-term net and short-term gross rates) can be explained by the relatively rapid degradation of a large proportion of the $\mathrm{Cl}_{\text {org, }}{ }^{11}$ and by the fact that mass balance calculations in field studies reflect the cumulative net increase of 
more refractory $\mathrm{Cl}_{\text {org }}$ only, while the laboratory experiments report gross rates.

$\mathrm{Cl}^{-}$Cycling. This study also provides information regarding how to interpret throughfall and stemflow, and regarding uptake and crown leaching, and associated internal cycling of $\mathrm{Cl}$ in plants. The stemflow contributed $1,14,11,11$, and $2 \%$ of the $\mathrm{Cl}^{-}$in (throughfall + stemflow in Figure 1) in the oak, beech, pine, Douglas fir, and Norway spruce stands, respectively. The estimated $\mathrm{Cl}^{-}$throughfall plus stemflow was substantially higher for black pine, Douglas fir, and Norway spruce than the atmospheric deposition (1.7 to >2.6 times higher). The atmospheric deposition was measured with an open deposition collector previously shown to capture both wet and dry deposition (dry deposition was $21 \%$ of the total deposition). ${ }^{34}$ It is sometimes assumed that $\mathrm{Cl}$ leaching from canopies is negligible and that throughfall represents one of the best estimates of stand-specific dry deposition. ${ }^{35,36}$ However, the $\mathrm{Cl}^{-}$levels in (throughfall and stemflow) from oak and beech were almost equal to the estimated total deposition (Figure 1), indicating a negligible contribution of dry deposition above what was captured in the open deposition collector. Further, Norway spruce stands had substantially lower (throughfall and stemflow) of $\mathrm{Cl}^{-}$than Douglas fir (Figure 1), despite having a larger standing foliage biomass $\left(31 \mathrm{t}\right.$ dry mass ha ${ }^{-1}$ versus $18 \mathrm{t}$ dry mass $\mathrm{ha}^{-1}$, respectively). ${ }^{37}$ Thus, throughfall was independent of foliage biomass, indicating that speciesdependent leaching could be more important for the observed differences between stands than possible differences in capturing dry deposition.

Further, even if assuming that $\mathrm{Cl}^{-}$dry deposition is $50 \%$ of the total deposition, as suggested for a spruce forest stand in Denmark (situated much closer to the coast than the Breuil site) ${ }^{38}$ the assumed additional dry deposition (not captured in the deposition collector) could not account for the high throughfall from spruce and Douglas fir canopies. Hence, dry deposition in excess of what was captured by the open deposition collections is not a likely major cause of the observed high levels of throughfall. Another potential contribution is horizontal deposition from, for example, fog or cloud droplets, but such deposition has primarily been shown significant along coasts or in mountain areas at altitudes $>800$ m.a.s.l., ${ }^{39,40}$ and is therefore most likely of minor importance in the studied location. Instead, substantial $\mathrm{Cl}^{-}$ canopy leaching, up to 12 -fold higher than incorporation in new biomass ( $\mathrm{Cl}$ immobilized in the new ligneous biomass produced), and $30-80 \%$ of the tree uptake (i.e., use for growth and return to the soil), is hypothesized to be a more likely explanation, given the mass balance calculations (Table 2).

In support of significant root uptake of $\mathrm{Cl}$ and further recycling through canopy leaching, Thimonier et al. $^{41}$ investigated $\mathrm{Cl}^{-}$deposition (bulk deposition and throughfall) patterns in 11 sites in Switzerland and found a seasonal pattern of $\mathrm{Cl}^{-}$deposition and especially for throughfall indicating a significant canopy leaching of $\mathrm{Cl}^{-}$. More specifically, $\mathrm{Na}: \mathrm{Cl}$ ratios in throughfall from different forest types were lower than bulk precipitation, and showed a strong seasonal pattern with the lowest $\mathrm{Na}: \mathrm{Cl}$ ratio during the growth season when trees were physiologically active. ${ }^{41}$ The observed $\mathrm{Cl}$ enrichment of throughfall during the growth season, combined with the reduction of $\mathrm{Cl}^{-}$content in senescing foliage, is also logical given the high internal transfers and further foliage leaching that have been observed for some other water-soluble ions in plants, for example, $\mathrm{K}^{+}$and $\mathrm{Cs}^{+},{ }^{42}$ with $\mathrm{K}^{+}$being correlated with leaching of organic matter and thereby with plant productivity. ${ }^{43}$ A similar "luxury consumption" is known for calcium (a major nutrient) ${ }^{44}$ and has been found for uranium (a nonessential element), ${ }^{45}$ but the elements taken up in excess, mainly sequestered in senescing foliage, were largely returned to the soil through litterfall and not by leaching as seems to be the case for $\mathrm{Cl}^{-}$. In summary, these results indicate that dry deposition may not be easily estimated from throughfall and wet deposition, and that the possibility of substantial canopy leaching must be considered (along with contributions from potential horizontal deposition in areas where, for example, fog and near ground clouds are common).

Given the estimated differences between plots in canopy leaching, the $\mathrm{Cl}^{-}$uptake by different trees likely differed substantially. Extensive $\mathrm{Cl}^{-}$uptake by plants and high betweenspecies differences in uptake rates have been confirmed for various agricultural plants (e.g., radish, lettuce, bean, and wheat). ${ }^{27}$ The soil-plant concentration ratio (CR) varied greatly between studied crops with lowest for radish and highest for wheat straw. Based on previous literature, a significant uptake in the plant biota is clear, however the information regarding trees and especially canopy exchange is much more scattered. The studies generally focus on salinity effects on tree growth on for instance oak and tamarack. ${ }^{46,47}$ Given the limited knowledge on uptake of $\mathrm{Cl}^{-}$by trees in terms of rates and mechanisms, this study calls for further studies on the role of both $\mathrm{Cl}^{-}$and $\mathrm{Cl}_{\text {org }}$ in various tree species.

Estimated Chlorine Residence Times. Average residence times of $\mathrm{Cl}^{-}$in trees and humus ranged from 0.6-6.2 and 0.10.9 years, respectively (Table 3 ). The residence time of $\mathrm{Cl}^{-}$in trees was highest in the oak plots, while humus $\mathrm{Cl}^{-}$residence times were highest in Norway spruce stands. The corresponding estimates of residence times of $\mathrm{Cl}_{\text {org }}$ in trees and humus ranged from 3.3-32 and 11-65 years, respectively (Table 3); the highest values being found for the coniferous tree stands. The residence times for $\mathrm{Cl}_{\text {org }}$ in the humus are theoretical and represent aggregated average values for very complex mixtures of compounds. They are also based on the assumption that $\mathrm{Cl}_{\text {org }}$ is degraded as the average organic matter. If the average $\mathrm{Cl}_{\text {org }}$ is more refractory than the average organic matter, in line with the persistence of many known organochlorine pollutants, the $\mathrm{Cl}_{\text {org }}$ residence times are underestimated. The results of this study confirm previous data indicating that $\mathrm{Cl}_{\text {org }}$ greatly affects the residence time of $\mathrm{Cl}$ in soils, ${ }^{6}$ and in addition highlight the importance of dominating tree species for soil and ecosystem $\mathrm{Cl}$ residence times.

The Importance of Trees for $\mathrm{Cl}$ Cycling. The reasons for the observed large spatial variability in $\mathrm{Cl}^{-}$and $\mathrm{Cl}_{\text {org }}$ in previous studies have so far been elusive. It has been speculated that the explanations are related to climate, $\mathrm{Cl}^{-}$deposition, vegetation, soil organic matter, or soil $\mathrm{pH} .{ }^{6,22,48}$ Our results show that tree species affect transformations and residence times of $\mathrm{Cl}$ in the trees and in the upper layer of the soil. Some of the other factors that have been suggested to be related to trees, such as microbial communities, $\mathrm{pH}$, root development, soil organic matter content and turnover ${ }^{49}$ may still be important in the frameworks defined by the tree community, but further studies are necessary to reveal the mechanisms behind the observed effects of our experimental treatments. Apart from demonstrating a major influence of tree species on processes regulating $\mathrm{Cl}$ cycling, the results presented here also show that $\mathrm{Cl}^{-}$and $\mathrm{Cl}_{\text {org }}$ levels can change dramatically in surface soil layers in situ over time frames as short as decades. This time development 
perspective is interesting as the balance between overall bulk organic matter chlorination and dechlorination processes is presently unclear and therefore it has not been known how fast the overall soil $\mathrm{Cl}_{\text {org }}$ levels can change. The present results of large increases in soil $\mathrm{Cl}_{\text {org }}$ levels over a few decades yield questions about dechlorination rates in nature, including both full mineralization of $\mathrm{Cl}_{\text {org }}$ and also selective removal of $\mathrm{Cl}$ atoms from organic compounds by, for example, reductive dehalogenation. ${ }^{50}$

The results of this study have fundamental implications for our view of the biogeochemical $\mathrm{Cl}$ cycle. The influences of tree species (including direct and indirect effects), and the rapid cycling of some $\mathrm{Cl}$ pools, whereas other pools have very long residence times, needs to be considered in all studies of $\mathrm{Cl}$ in terrestrial environments, agricultural practices and land use changes. $^{51}$ These results challenge hydrological or risk assessment models that consider $\mathrm{Cl}^{-}$to be inert, as vegetation can be a rapidly changing driver in the $\mathrm{Cl}$ cycle given, for example, human land-use. Further, this study implies that unwanted organochlorines or radioactive chlorine can stay and expose organisms for longer time and occur at higher levels in areas with certain vegetation types. The results also highlight how we may affect terrestrial cycling by land-use change through the vegetation and this opens the possibility of managing $\mathrm{Cl}$ cycling through control of tree species composition.

\section{ASSOCIATED CONTENT}

\section{S Supporting Information}

Additional information as noted in the text. This material is available free of charge via the Internet at http://pubs.acs.org.

\section{AUTHOR INFORMATION}

\section{Corresponding Author}

*Phone: +46 13 282179; e-mail: malin.montelius@liu.se.

\section{Author Contributions}

Y.T., L.M., M.M., and D.B. planned the study. Y.T., J.-T.C., and J.R. supplied the sample material. Analyses were performed by M.M., T.S., J.-T.C., and J.R.. M.M. and D.B. wrote the first draft of the manuscript, and all authors contributed to the development of the text. Funding was provided through work by Y.T., L.M., and D.B.

\section{Notes}

The authors declare no competing financial interest.

\section{ACKNOWLEDGMENTS}

This study was supported by EDF, France, French national radioactive waste management agency (Andra), France, and Linköping University, Sweden. J-T. C. is supported by "Fonds National de la Recherche Scientifique" (FNRS) of Belgium. We thank Lena Lundman, Susanne Karlsson, and Henrik Reyier for valuable practical assistance.

\section{REFERENCES}

(1) Hobbie, S. E. Effects of plant species on nutrient cycling. Tree 1992, 7 (10), 336-339.

(2) Carnol, M.; Bazgir, M. Nutrient return to the forest through litter and throughfall under 7 forest species after conversion from Norway spruce. For. Ecol. Manage. 2013, 309, 66-75.

(3) Smethurst, P. Nutritional physiology of trees. Tree Physiol. 2004, $1616-1622$.
(4) Kirchner, J. W.; Feng, X. H.; Neal, C. Fractal stream chemistry and its implications for contaminant transport in catchments. Nature 2000, 403, 524-527.

(5) Johansson, E.; Sandén, P.; Öberg, G. Spatial patterns of organic chlorine and chloride in Swedish forest soil. Chemosphere 2003, 52, 391-397.

(6) Redon, P. O.; Abdelouas, A.; Bastviken, D.; Cecchini, S.; Nicolas, M.; Thiry, Y. Chloride and organic chlorine in forest soils: Storage, residence times, and influence of ecological conditions. Environ. Sci. Technol. 2011, 45, 7202-7208.

(7) Bastviken, D.; Svensson, T.; Karlsson, S.; Sandén, P.; Öberg, G. Temperature sensitivity indicates that chlorination of organic matter in forest soil is primarily biotic. Environ. Sci. Technol. 2009, 43, 35693573.

(8) Rohlenova, J.; Gryndler, M.; Forczek, S. T.; Fuksová, K.; Handova, V.; Matucha, M. Microbial chlorination of organic matter in forest soil: Investigation using Cl-36-chloride and its methodology. Environ. Sci. Technol. 2009, 43, 3652-3655.

(9) Lee, R. T.; Shaw, G.; Wadey, P.; Wang, X. Specific association of ${ }^{36} \mathrm{Cl}$ with low molecular weight humic substances in soils. Chemosphere 2001, 43, 1063-1070.

(10) Myneni, S. Formation of stable chlorinated hydrocarbons in weathering plant material. Science 2002, 295, 1039-1041.

(11) Leri, A. C.; Myneni, S. C. B. Organochlorine turnover in forest ecosystems: The missing link in the terrestrial chlorine cycle. Global Biogeochem. Cycles 2010, 24, GB4021.

(12) Clarke, N.; Fuksova, K.; Gryndler, M.; Lachmanova, Z.; Liste, H. H.; Rohlenova, J.; Schroll, R.; Schröder, P.; Matucha, M. The formation and fate of chlorinated organic substances in temperate and boreal forest soils. Environ. Sci. Pollut. Res. 2009, 16, 127-143.

(13) Redon, P.-O.; Jolivet, C.; Saby, N. P-A.; Abdelouas, A.; Thiry, Y. Occurrence of natural organic chlorine in soils for different land uses. Biogeochemistry 2013, 114, 413-419.

(14) Hunter, J. C.; Belt, A.; Sotos, L. S.; Fonda, M. E. Fungal chloroperoxidase method. 1987 United States Patent US4937192, USA.

(15) De Jong, E.; Field, J. A. Sulphur Taft and Turkey Tail: Biosynthesis and biodegradation of organohalogenes by basidiomycetes. Annu. Rev. Microbiol. 1997, 51, 375-414.

(16) Öberg, G. The natural chlorine cycle-Fitting the scattered pieces. Appl. Microbiol. Biotechnol. 2002, 58, 565-581.

(17) Bengtson, P.; Bastviken, D.; de Boer, W.; Öberg, G. Possible role of reactive chlorine in microbial antagonism and organic matter chlorination in terrestrial environments. Environ. Microbiol. 2009, 11 (6), 1330-1339.

(18) Bengtson, P.; Bastviken, D.; Öberg, G. Possible role of reactive chlorine II: Assessing biotic chlorination as a way for organisms to handle oxygen stress. Environ. Microbiol. 2013, 15 (4), 991-1000.

(19) White, P.; Broadley, M. Chloride in soils and its uptake and movement within the plant: A review. Ann. Bot. 2001, 88, 967-988.

(20) Van den Hoof, C.; Thiry, Y. Modelling of the natural chlorine cycling in a coniferous stand: Implications for chlorine-36 behaviour in a contaminated forest environment. J. Environ. Radioact. 2012, 107, $56-67$.

(21) Bastviken, D.; Sandén, P.; Svensson, T.; Stahlberg, C.; Magounakis, M.; Öberg, G. Chloride retention and release in a boreal forest soil - effects of soil water residence time and nitrogen and chloride loads. Environ. Sci. Technol. 2006, 40, 2977-2982.

(22) Gustavsson, M.; Karlsson, S.; Öberg, G.; Sandén, P.; Svensson, T.; Valinia, S.; Thiry, Y.; Bastviken, D. Organic matter chlorination rates in different boreal soils: The role of soil organic matter content. Environ. Sci. Technol. 2012, 46, 1504-1510.

(23) Öberg, G.; Bastviken, D. Transformation of chloride to organic chlorine in terrestrial environments: Variability, extent, and implications. Crit. Rev. Environ. Sci. Technol. 2012, 42 (23), 25262545.

(24) Johansson, E.; Sandén, P.; Öberg, G. Organic chlorine in deciduous and coniferous forest soil, southern Sweden. Soil Sci. 2003, $168,347-355$. 
(25) Calvaruso, C.; ŃDira, V.; Turpault, M.-P. Impact of common European tree species and Douglas-fir (Pseudotsuga menziesii [Mirb.] Franco) on the physicochemical properties of the rhizosphere. Plant Soil 2011, 342, 469-480.

(26) Prescott, C. E.; Grayston, S. J. Tree influence on microbial communities in litter and soil. Current knowledge and research needs. For. Ecol. Manage. 2013, 309, 19-27.

(27) Kashparov, V.; Colle, C.; Zvarich, S.; Yoschenko, V.; Levchuk, S.; Lundin, S. Soil-to-plant halogens transfer studies 2. Root uptake of radiochlorine by plants. J. Environ. Radioact. 2005, 79, 233-253.

(28) Kashparov, V.; Colle, C.; Levchuk, S.; Yoschenko, V.; Zvarich, S. Radiochlorine concentration ratios for agricultural plants I various conditions. J. Environ. Radioact. 2007, 95, 10-22.

(29) Öberg, G.; Johansen, C.; Grøn, C. Organic halogens in spruce forest throughfall. Chemosphere 1998, 36, 1689-1701.

(30) Öberg, G.; Grøn, C. Sources of organic halogens in a Danish spruce forest soil. Environ. Sci. Technol. 1998, 32, 1573-1579.

(31) Cornelis, J. T.; Ranger, J.; Iserentant, A.; Delvaux, B. Tree species impact the terrestrial cycle of silicon through various uptakes. Biogeochemistry 2010, 97, 231-245.

(32) Water Quality Determination of Dissolved Fluoride, Chloride, Nitrite, Orthophosphate, Bromide, Nitrate and Sulphate Ions, Using Liquid Chromatography of Ions Part 1: Method for Water with Low Contamination; Standardization, E. C. f.: Brussels, 1995; ISO 10304$1: 1992$.

(33) Asplund, G.; Grimvall, A.; Jonsson, S. Determination of the total and leachable amounts of organohalogens in soil. Chemosphere 1994, 28, 1467-14.

(34) Ulrich, E.; Coddeville, P.; Lanier, M. Retombées atmosphériques humides en France entre 1993 et 1998; ADEME ed.s: Paris, 2002.

(35) Lovett, G. M.; Likens, G. E.; Buso, D. C.; Driscoll, C. T.; Bailey, S. W. The biogeochemistry of chlorine at Hubbard Brook, New Hampshire, USA. Biogeochemistry 2005, 72, 191-232.

(36) Svensson, T.; Lovett, G. M.; Likens, G. E. Is chloride a conservative ion in forest ecosystems? Biogeochemistry 2012, 107, 125-134.

(37) Sicard, C.; Saint-Andre, L.; Gelhaye, D.; Ranger, J. Effect of initial fertilisation on biomass and nutrient content of Norway spruce and Douglas-fir plantations at the same site. Trees Struct. Funct. 2006, 20, 229-246.

(38) Öberg, G.; Holm, M.; Sandén, P.; Svensson, T.; Parikka, M. The role of organic-matter-bound chlorine in the chlorine cycle: A case study of the Stubbetorp catchment, Sweden. Biogeochemistry 2005, 75, 241-269.

(39) Zimmermann, L.; Zimmermann, F. Fog deposition to Norway Spruce stands at high-elevation sites in the Eastern Erzgebirge (Germany). J. Hydrol. 2002, 256, 166-175.

(40) Lange, C. A.; Matschullat, J.; Zimmermann, F.; Sterzik, G.; Wienhaus, O. Fog frequency and chemical composition of fog waterA relevant contribution to atmospheric deposition in the eastern Erzgebirge, Germany. Atmos. Environ. 2003, 37, 3731-3739.

(41) Thimonier, A.; Schmitt, M.; Waldner, P.; Schleppi, P. Seasonality of the $\mathrm{Na} / \mathrm{Cl}$ ratio in precipitation and implications of canopy leaching in validating chemical analyses of throughfall samples. Atmos. Environ. 2008, 42, 9106-9117.

(42) Goor, F.; Thiry, Y. Processes, dynamics and modelling of radiocaesium cycling in a chronosequence of Chernobyl-contaminated Scots pine (Pinus sylvestris L.) plantations. Sci. Total Environ. 2004, 325, 163-180.

(43) Kopáček, J.; Turek, J.; Hejzlar, J.; Santruckova, H. Canopy leaching of nutrients and metals in a mountain spruce forest. Atmos. Environ. 2009, 43, 5443-5453.

(44) Van der Stegen, J.; Myttenaere, C. The K and Ca biogeochemical cycles in forest ecosystems: A review. Trends Soil Sci. 1991, 1, 271-276.

(45) Thiry, Y.; Schmidt, P.; Van Hees, M.; Wannijn, J.; Van Bree, P.; Rufyikiri, G.; Vandenhove, H. Uranium distribution and cycling in Scots pine (Pinus sylvestris L.) growing on a revegetated U-mining heap. J. Environ. Radioact. 2005, 81, 201-219.
(46) Renault, S. Tamarack response to salinity: Effects of sodium chloride on growth and ion, pigment, and soluble carbohydrate levels. Can. J. For. Res. 2005, 35, 2806-2812.

(47) Alaoui-Sossé, B.; Sehmer, L.; Barnola, P.; Dizengremel, P. Effect of $\mathrm{NaCl}$ salinity on growth and mineral partitioning in Quercus robur L., a rhythmically growing species. Trees 1998, 12, 424-430.

(48) Johansson, E.; Ebenå, G.; Sandén, P.; Svensson, T.; Öberg, G. Organic and inorganic chlorine in Swedish spruce forest soil: Influence of nitrogen. Geoderma 2001, 101, 1-13.

(49) Vesterdal, L.; Clarke, N.; Sigurdsson, B. D.; Gundersen, P. Do tree species influence soil carbon stocks in temperate and boreal forests? For. Ecol. Manage. 2013, 309, 4-18.

(50) Dolfing, J.; Tiedje, J. M. Acetate as a source of reducing equivalents in the reductive dechlorination of 2,5-dichlorobenzoate. Arch. Microbiol. 1991, 156, 356-361.

(51) Kopáček, J.; Hejzlar, J.; Porcal, P.; Posch, M. A mass-balance study on chlorine fluxes in a large central European catchment during 1900-2010. Biogeochemistry 2014, 120, 319-335. 